\title{
Recurrent cellulitis caused by an occult foreign body in a diabetic foot
}

\author{
Diarmuid Declan Sugrue 다 , Ciaran Stanley, Gavin McHugh
}

Department of Trauma and Orthopaedic Surgery, Beaumont Hospital, Dublin, Ireland

\section{Correspondence to} Dr Diarmuid Declan Sugrue; diarmuid.sugrue@ucdconnect.ie

Accepted 28 April 2021
Check for updates

(C) BMJ Publishing Group Limited 2021. No commercial re-use. See rights and permissions. Published by BMJ.

To cite: Sugrue DD,
Stanley C, McHugh G. BMJ
Case Rep 2021;14:e243514.
doi:10.1136/bcr-2021-
243514

\section{DESCRIPTION}

A 74-year-old farmer presented to the emergency department (ED) with a 5-day history of left leg pain, swelling and redness. He denied trauma or injury. Background medical history included type 2 diabetes mellitus, diabetic neuropathy, right lower limb lymphoedema, recurrent left leg and foot cellulitis and bilateral total knee replacements. $\mathrm{He}$ was a non-smoker and occasional drinker.

On examination, the patient was afebrile. Inspection revealed confluent erythema and oedema from the left knee to distal phalanges. A 'rocker-bottom' deformity of the foot was evident. Distal loss of pin, temperature and vibratory perception were evident bilaterally. Pressure sensation was absent when assessed with a $10 \mathrm{~g}$ monofilament. Laboratory investigations showed a white cell count of $14.6 \times 10^{9} / \mathrm{L}$ (reference range: $4.0 \times 10^{9} / \mathrm{L}-11.0 \times 10^{9} / \mathrm{L}$ ) and a Glycated Haemoglobn (Haemaglobin A1c) of $50 \mathrm{mmol} / \mathrm{mol}$ (reference range: $20-42 \mathrm{mmol} / \mathrm{mol}$ ).

Left lower limb cellulitis was diagnosed. Empiric intravenous flucloxacillin was commenced. This yielded little improvement after 1 week. An MRI study of the left foot on day 8 of admission showed extensive Charcot arthropathy with osteomyelitis of the third and fourth metatarsals. A foreign body was seen embedded within the subcutaneous tissue of the dorsum of the midfoot, with a reported abscess measuring $17 \times 12 \times 8 \mathrm{~mm}$ extending to the proximal intermetatarsal space (figure 1/video 1 ). This was not reported on or appreciable in prior plain-film radiographs (X-rays) of the foot.

The object was excised under general anaesthetic on admission day 15 . A $3-\mathrm{cm}$ longitudinal incision was made over the object (figure 2). A plastic lid measuring $1.5 \times 1.5 \times 1 \mathrm{~cm}$ was identified and dissected free (figure 2). There was no evidence of any surrounding infection or collection at time of surgery. The wound was washed with betadine and closed with interrupted 3-0 nylon sutures.

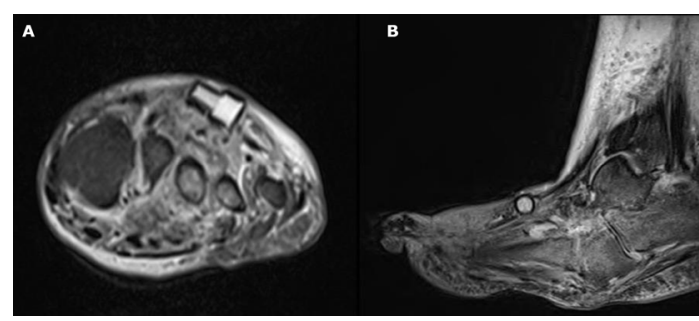

Figure 1 T1-weighted magnetic resonance sequence of left foot in (A) coronal and (B) sagittal planes, demonstrating embedded foreign object overlying the dorsal aspect of the third and fourth metatarsals.

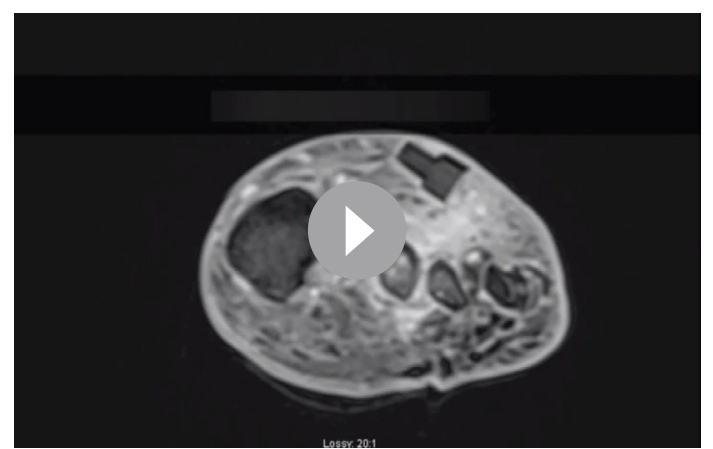

Video 1 T2-weighted magnetic resonance sequence of left foot in coronal plane, demonstrating embedded foreign object overlying the dorsal aspect of the third and fourth metatarsals.

The patient was discharged on postoperative day 14 and received outpatient intravenous antibiotics for further 4 weeks. He has since made a complete recovery.

Foreign bodies may be retained in the foot for a significant time before diagnosis, particularly in those with peripheral neuropathy. Foreign bodies may be a source of acute or chronic infection; numerous authors report osteomyelitis of the foot in the setting of occult foreign bodies. ${ }^{12}$ We suspect that the plastic cap in our case was a remanent from an intravenous or negative pressure wound therapy set, embedded following debridement and washout

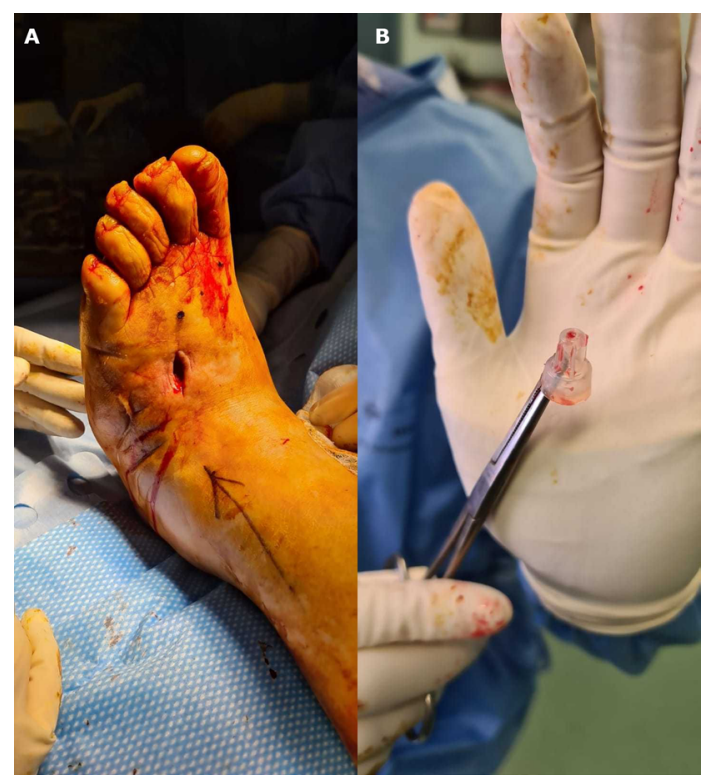

Figure 2 (A) A 3-cm incision was made over the object. (B) A plastic lid was removed from the foot. 


\section{Patient's perspective}

I've had an awful lot of infections in the left foot. It started off in 2010. I was in hospital twice for 5 days. It was the same in 2011 and 2012. I then had infections up to 2014, always on the same side. I was in hospital for 4 days or 5 days two times a year.

The real bad infection was the one where the big abscess came in 2011. That's when it had to be lanced and that's when that (the foreign body) happened. The nurse came out to the house when I came home and she was dressing it every second day. She put a sort of gauze into the opening and then they put the dressing on top of the gauze. It took ages to heal.

After it all healed up I did notice when you put your finger on top of the foot it used to feel sore ... if you pressed down ... I didn't know what it was. But it didn't bother me. It didn't affect my walking.

This time (the infection) started in the foot and went up me leg. Me mobility went altogether. I could hardly walk. I didn't feel well at home for two weeks, I should have been in hospital sooner. I went to bed one night not anything on me and I woke up at $3 \mathrm{o}^{\prime}$ clock in the morning shivering and sweating and my leg - you could fry eggs on it! I'd a carer coming in and she could see me mobility was getting worse and she said that's enough of this and she rang the doctor and got an ambulance then. They told me I'd an infection in the good leg. They scanned the foot because they thought it might have started there.

It's a mystery (the foreign object). When the doctor came up to me one morning and said to me, 'There's a foreign body in your foot', I thought she was joking! I went to laugh and she says I'm telling the truth, I thought she was joking. I don't know what it is. They showed me a photograph of it, but I don't know what it is. I didn't know it was in there. I suppose I'll be lonely now without my friend!

\section{Learning points}

- The absence of pain secondary to peripheral neuropathy may mask symptoms from a foreign body or other pathology.

- MRI should be considered in patients with recurrent ipsilateral cellulitis.

- Treatment should include surgical removal of the foreign body, antibiotics and glycaemic control. of an abscess 10 years prior in another institution. While impacted insulin needles have been described in diabetic feet, ${ }^{3}$ to the best of our knowledge, this is the first case of a retained fragment from such a set. A 'surgical count' should be standard practice when changing dressings on chronic wounds. ${ }^{4}$

Foot infections can be underestimated in patients with diabetes and may occasionally be due to foreign bodies. In particular, the inflammatory response may be underwhelming in subfascial sepsis, and crepitus missed in those with arthropathy. The absence of pain secondary to peripheral neuropathy may mask a foreign body. ${ }^{5}$

Ultrasound, CT or MRI can be used to evaluate foreign bodies. MRI is particularly useful in diabetic feet for evaluating soft tissue abnormalities such as cellulitis, abscesses, gangrene or foreign body granulomas. ${ }^{6}$

An accessible foreign body should be removed. All patients with diabetes should undergo comprehensive foot evaluation annually. ${ }^{7}$ Bare foot walking should be avoided, and all patients should be educated regarding appropriate footwear and foot hygiene.

Contributors DDS and CS wrote the manuscript. GM reviewed the manuscript. All authors approved the final manuscript.

Funding The authors have not declared a specific grant for this research from any funding agency in the public, commercial or not-for-profit sectors.

Competing interests None declared.

Patient consent for publication Obtained.

Provenance and peer review Not commissioned; externally peer reviewed.

\section{ORCID iD}

Diarmuid Declan Sugrue http://orcid.org/0000-0003-0811-4224

\section{REFERENCES}

1 Greene WB. Unrecognized foreign body as a focus for delayed Serratia marcescens osteomyelitis and septic arthritis. two case reports. J Bone Joint Surg Am 1989;71:754-7.

2 Chandrashekara CM, George MA, Al-Marboi BSK. Neglected foreign body, the cause of navicular osteomyelitis in a paediatric foot: a case report. J Orthop Case Rep 2013;3:26-9.

3 Nadig SN, Deibler AR, Marlow T, et al. Retained needle fragments in patients with diabetic neuropathy. JAMA 2000;283:3072.

4 Isaac A. Addressing complications with negative pressure wound therapy use. PodiatryToday 2019;32:44-9 https://www.podiatrytoday.com/addressingcomplications-negative-pressure-wound-therapy-use

5 Naraynsingh V, Maharaj R, Dan D, et al. Puncture wounds in the diabetic foot: importance of X-ray in diagnosis. Int J Low Extrem Wounds 2011;10:98-100.

6 Russell JM, Peterson JJ, Bancroft LW. Mr imaging of the diabetic foot. Magn Reson Imaging Clin N Am 2008;16:59-70.

7 American Diabetes Association. 10. Microvascular Complications and Foot Care: Standards of Medical Care in Diabetes-2018. Diabetes Care 2018;41:S105-18.

Copyright 2021 BMJ Publishing Group. All rights reserved. For permission to reuse any of this content visit

https://www.bmj.com/company/products-services/rights-and-licensing/permissions/

BMJ Case Report Fellows may re-use this article for personal use and teaching without any further permission.

Become a Fellow of BMJ Case Reports today and you can:

- Submit as many cases as you like

- Enjoy fast sympathetic peer review and rapid publication of accepted articles

- Access all the published articles

- Re-use any of the published material for personal use and teaching without further permission

Customer Service

If you have any further queries about your subscription, please contact our customer services team on +44 (0) 2071111105 or via email at support@bmj.com.

Visit casereports.bmj.com for more articles like this and to become a Fellow 